\title{
DETERMINATION OF MICROBIAL LOAD IN RESTAURANT FOODS SOLD WITHIN OZORO ISOKO NORTH, DELTA STATE OF NIGERIA
}

\author{
${ }^{1}$ APHIAR AGNES E and ${ }^{2}$ RAPHAEL NATHAN IKECHUKWU \\ ${ }^{1}$ Department of Science Laboratory Technology \\ Delta State Polytechnic, Delta State Ozoro \\ ${ }^{2}$ Emore Grammer School, Oleh, Delta State \\ Nigeria
}

\begin{abstract}
Samples of foods were collected from the different restaurant within Ozoro metropolis to determine the microbial quality. 10 samples were collected from five various sites. From the analysis Escheerchia coil, Staphylococus aureus, Bacilluus spp, Lactobacillus spp, Pseudomonas aeruginosa, Rhizopus spp, Aspergillus spp, and Mucor spp were isolated. The total bacteria and fungi count ranged from 1.0x103cfc/g. Those foods whose counts ranged from 1.0x103to 3.5x103cfc/g were acceptable with reference to hazard analysis critical control point, therefore, present finding call for the more stringent supervision by the public health department of the local government authority, staff and the general public from the further occurrence of food poisoning.
\end{abstract}

Keywords: Microbial Load, Restaurant, Food Quality.

\section{INTRODUCTION}

Food is any substance normally eaten or drunk by living things. The term food also includes liquid drinks. Food is the main sources of energy and of nutrition for animals, and is usually of animals or plant origin. There are 4(four) basic food energy sources, fats proteins, carbohydrates and alcohol (Wikipedia, 2018).

Microbial load is the total number of bacteria and fungi in a given quantity of water or soil or on the surface of food or an environment. The presence of the bacteria and fungi may not be related to the presence of disease causing organisms (Odika, 2011).

There is a wide variety of restaurant food, but are not limited to sandwiches, kebabs, sushi, take away foods and bakery products. A Restaurant foods usually include a number of ingredients which may or may not be cooked due to the variety of restaurants foods. The interpretation of microbial result obtained from testing must account for the method of processing and the individual components of the food (FSANZ, 2001).

Raw foods especially restaurant vegetables salads. Sprouts have been implicated in outbreak of food borne diseases in both developed countries like USA, China and developing countries like Ghana and Nigeria (Kumar et al., 2006).

In countries were local restaurants foods is prevalent, there is commonly a lack of information on the incident of food borne disease related to the local restaurant foods (WHO, 2001).

In Nigeria, food are sold at all public places and road side shops. However, there consumption, quick method of cleaning and handling could often prove to be a public health threat. There are reports of food-borne diseases associated with the consumption of unhygienic foods at several places in Nigeria. Hazards analysis and critical point (HACCP) conducted for some selected local food restaurants and fast food se involve microbial analysis of food samples indicative of personal hygiene and environmental sanitation showed the presence of E.coli in almost all the sample salmonella and stigella in knife, hand rinse and dish washer ( Sheth et al., 2005).

Local food restaurants usually make use of simple facilities like wheelbarrows, trays, mat, tables and make shift stall, thus further increasing the risk of contamination from raw materials and equipment additional processing condition, improper handling and prevalence of unhygienic condition contributes substantially to the entering of bacteria pathogen (Mahale et al., 2008).

There are basically two major sources in which microbes can get into our foods these sources includes the primary or natural sources and the secondary or artificial sources. The primary or natural sources include the surrounding soil, water, dust particles. 
The micro-organism found in these sources are Bacillus spp, Salmonella spp, Aspergillus spp, Penicillum spp and Yeast (Cliffs, 2000).

The secondary or artificial sources include food handlers, food utensils and the food handlers garments. Macro-organism presents in this sources are variety of organism (Cliffs, 2000).

This pathogens can cause two types of food borne illness-the diarrhea type and the emetic or vomiting type. The diarrhea type occurs within 8 to 16 hours eating food and last for about 24 hours. Food involved vary from starch, vegetables, meat products, cereal foods, sauces, puddings spices (Food Safety Information Council, 2003)

\section{THE STUDY AREA}

Ozoro is the administrative headquarters of Isoko North Local government area of Delta State. It is located in the Southern part of Nigeria and is inhabited by an ethnic group of the same name, the Isoko people. Ozoro region is in the tropical rain forest area of the Nigeria Delta. The region experiences high rainfall and high humidity most of the year. The climate is equatorial and is marked by two distinct seasons. The dry season lasts from about November to April and is significantly marked by the cool harmattan dusty haze from the North-east winds. The rainy season May to October with a brief dry spell (Wikipedia 2018).

\subsection{Sample Collection}

The samples were collected at Ozoro Delta state in five various cooked food in different restaurants, two samples from each restaurant. The restaurant food are moi-moi and beans from restaurant A, Egusi soup (Mellon) and Jollof rice from restaurant B, Starch and banga soup from restaurant C, Stew and Ogbolor soup from restaurant D, Salad and plantain from restaurant E.

\section{MATERIALS AND METHOD}

\subsection{Preparation of Media}

\section{Nutrient Agar:}

Materials: cotton wool, Aluminum foil, conical flask, Autoclave, Sterile water.

$7 \mathrm{~g}$ of nutrient agar was suspended in $250 \mathrm{ml}$ of distilled water. It was shaken carefully so as to dissolve completely. Cotton wool was wrapped in aluminum foil and was used to cover the mount of the conical 2 flask which was transferred to the autoclave for sterilization. It was autoclave for $15 \mathrm{mins}$ at $121^{\circ} \mathrm{C}$. After autoclave, the conical flask was placed on the laboratory bench so as to allow it to cool to $47^{\circ} \mathrm{C}$ before dispensing about $15-20 \mathrm{ml}$ into the sterilized petri dishes.

\section{MAC Conkey Agar}

This agar is used for differentiating intestinal organism into lactose and non-lactose fermenting organism. 13g of the MC conkey agar was dispensed into $250 \mathrm{ml}$ of sterile water in conical flask. It was properly mixed and the mouth of the conical flask was covered with cotton wool wrapped in aluminum foil before transferring into the autoclave for autoclaving at $121^{\circ} \mathrm{C}$ for $15 \mathrm{mins}$. It was then placed in the working bench and allowed to cool at about $47^{\circ} \mathrm{C}$ about $15-20$ was dispensed into the sterile petri dishes which were allowed to solidify

\section{Potatoe Dextrose Agar (pda)}

$10 \mathrm{~g}$ of the PDA was dispensed into $250 \mathrm{ml}$ of sterile water in a conical flask. Then it was shaken properly to dissolve all the powder. It was cover with cotton wool wrapped with aluminum foil and placed in an auto clave for auto calving at about $121^{0} \mathrm{C}$ for $15 \mathrm{mins}$ after which the conical flask was placed on a sterile laboratory bench and allowed to cool at about $47^{\circ} \mathrm{C}$ before pouring $25-20 \mathrm{ml}$ of the agar in a sterile petri dishes. It was then allowed to solidify.

\section{Microbiological Evaluation:}

The microbial statuses of the different cooked food collected from different restaurant were investigated.

\section{Characterization of Bacteria Isolate}

Identification was done by consideration of the culture morphological biochemical characteristics of each isolates and in accordance to the district and the eight edition of Bergey's manual of determinative bacteriology.

\section{Biochemical Characterization}

Biochemical characterization of the isolate colonies was carried using standard protocols. Identification was carried out according to Bergey's Manual.

\section{RESULT AND DISCUSSION}


International Journal of Advances in Scientific Research and Engineering (ijasre), Vol 5 (6), June-2019

A total of ten cooked food samples were examined in this research study. The samples collected aseptically in sterile container after been tested revealed pathogenic contamination with feacal coalition in majority of them. Bacterial enumeration revealed a high count of feacal streptococci indicating poor bacteriology of the cooked food. The significant result of bacterial/fungal enumeration are presented in the table below

Table 1: Restaurant 1

\begin{tabular}{|l|l|l|c|l|}
\hline & \multicolumn{3}{|c|}{ BACTERIAL COUNT } & Fungal Count \\
\hline Samples & N/A (cuf/g) & Mac $(\mathrm{cuf} / \mathrm{g})$ & CLEO $(\mathrm{cuf} / \mathrm{g})$ & PDA (cuf/g) \\
\hline $\mathrm{A}$ & $1.0 \times 10^{-3}$ & $1.1 \times 10^{-3}$ & Nil & Nil \\
\hline $\mathrm{B}$ & $2.0 \times 10^{-3}$ & $1.0 \times 10^{-3}$ & $1.5 \times 10^{-3}$ & $1.8 \times 10^{-3}$ \\
\hline
\end{tabular}

Table 2: Restaurant 2

\begin{tabular}{|l|l|l|l|l|}
\hline & \multicolumn{3}{|c|}{ BACTERIAL COUNT } & Fungal Count \\
\hline Samples & N/A (cuf/g) & Mac $(\mathrm{cuf} / \mathrm{g})$ & CLEO $(\mathrm{cuf} / \mathrm{g})$ & PDA $(\mathrm{cuf} / \mathrm{g})$ \\
\hline A & $1.5 \times 10^{-3} \mathrm{Nil}$ & $1.2 \times 10^{-3}$ & & Nil \\
\hline B & $1.1 \times 10^{-3}$ & Nil & $1.0 \times 10^{-3}$ & $1.3 \times 10^{-3}$ \\
\hline
\end{tabular}

Table 3: Restaurant 3

\begin{tabular}{|l|l|l|l|l|}
\hline & \multicolumn{3}{|c|}{ BACTERIAL COUNT } & Fungal Count \\
\hline Samples & N/A (cuf/g) & Mac (cuf/g) & CLEO(cuf/g) & PDA (cuf/g) \\
\hline A & $1.2 \times 10^{-3}$ & $1.0 \times 10^{-3}$ & $1.1 \times 10^{-3}$ & $2.1 \times 10^{-3}$ \\
\hline B & $4.5 \times 10^{-3}$ & $4.8 \times 10^{-3}$ & $1.8 \times 10^{-3}$ & $2.1 \times 10^{-3}$ \\
\hline
\end{tabular}

Table 4: Restaurant 4

\begin{tabular}{|l|l|l|l|l|}
\hline & \multicolumn{3}{|c|}{ BACTERIAL COUNT } & Fungal Count \\
\hline Samples & N/A (cuf/g) & Mac (cuf/g) & CLEO $(\mathrm{cuf} / \mathrm{g})$ & PDA (cuf/g) \\
\hline A & $1.9 \times 10^{-3} \mathrm{Nil}$ & $1.6 \times 10^{-3}$ & & $1.9 \times 10^{-3}$ \\
\hline $\mathrm{B}$ & $2.8 \times 10^{-3}$ & $4.2 \times 10^{-3}$ & $9.9 \times 10^{-3}$ & $2.8 \times 10^{-3}$ \\
\hline
\end{tabular}

Table 5: Restaurant 5

\begin{tabular}{|l|l|l|l|l|}
\hline & \multicolumn{3}{|c|}{ BACTERIAL COUNT } & Fungal Count \\
\hline Samples & N/A (cuf/g) & Mac $(\mathrm{cuf} / \mathrm{g})$ & CLEO(cuf/g) & PDA (cuf/g) \\
\hline A & $4.1 \times 10^{-3}$ & $4.2 \times 10^{-3}$ & $4.6 \times 10^{-3}$ & $4.4 \times 10^{-3}$ \\
\hline B & $1.3 \times 10^{-3}$ & $1.8 \times 10^{-3}$ & $1.1 \times 10^{-3}$ & $1.3 \times 10^{-3}$ \\
\hline
\end{tabular}

Table 6: Characterization and Identification of Bacterial Isolates

\begin{tabular}{|l|l|l|l|l|l|l|l|l|l|l|}
\hline \multicolumn{2}{|c|}{ MORPHOLOGY } & \multicolumn{3}{l|}{ BIOCHEMICAL TEST } \\
\hline Staining & Cell Shape & & & \\
\hline
\end{tabular}

Table7: Restaurant One 
International Journal of Advances in Scientific Research and Engineering (ijasre), Vol 5 (6), June-2019

\begin{tabular}{|l|l|l|l|l|l|l|l|l|l|l|l|l|}
\hline A & +++ & Rods & Rods & Rods & - & - & - & Acid/g & Acid/g & - & + & E.Spp \\
\hline B & +++ & Rods & Long Chain & Cocci & ++ & - & Acid & Acid & - & - & - & $\begin{array}{l}\text { staphylococcu } \\
\text { s }\end{array}$ \\
\hline
\end{tabular}

Table 8: Restaurant two

\begin{tabular}{|l|l|l|l|l|l|l|l|l|l|l|l|l|l|}
\hline A & + & + & Long & Rods & Cocci & ++ & Acid/g & Acid/g & - & - \\
B & + & + & + & $\begin{array}{l}\text { Long } \\
\text { Chain }\end{array}$ & Rods & Cocci & +++ & Acid/g & Acid/g & - \\
\hline
\end{tabular}

Table 9:Restaurant Three

\begin{tabular}{|l|l|l|l|l|l|l|l|l|l|l|l|l|l|l|}
\hline A & +++ & Long & Rods & Rod & & ++ & Acid/g & Acid/g & - \\
\hline B & ++ & + & $\begin{array}{l}\text { Long } \\
\text { Chain }\end{array}$ & Rods & Rods & -- & - & Acid/g & Acid/g & - & + & - \\
\hline
\end{tabular}

Table 10:Restaurant Four

\begin{tabular}{|l|l|l|l|l|l|l|l|l|l|l|l|l|l|l|l|}
\hline A & ++ & + & Rods & Cocci & Rod & + & - & + & Acid/g & Nil & - & - & Staphy Aureus \\
\hline B & ++ & & & & & & & & & & & & & & \\
\end{tabular}

Table 11: Restaurant Five

\begin{tabular}{|c|c|c|c|c|c|c|c|c|c|c|c|c|c|c|c|}
\hline $\mathrm{A}$ & + & + & + & Rods & Rods & Rod & + & - & + & Acid/g & Nil & + & - & + & Bacillus \\
\hline B & + & + & + & Rods & Rods & Rod & - & - & - & Acid/g & Acid/g & - & + & - & E. spp \\
\hline
\end{tabular}


International Journal of Advances in Scientific Research and Engineering (ijasre), Vol 5 (6), June-2019



Fig. 1: Bacterial count for Restaurant 1

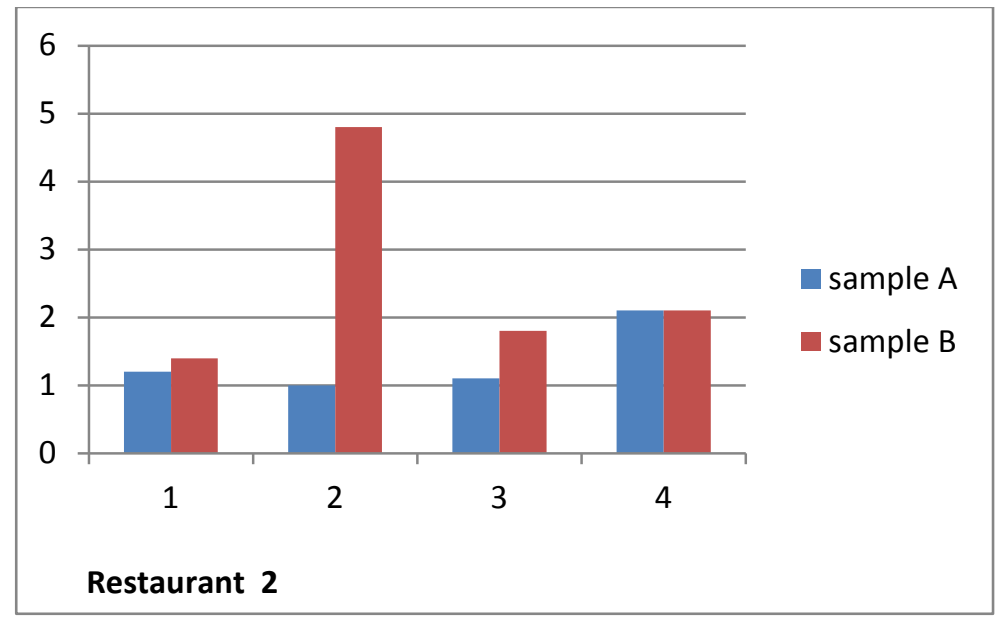

Fig. 2: Bacterial count for Restaurant 2

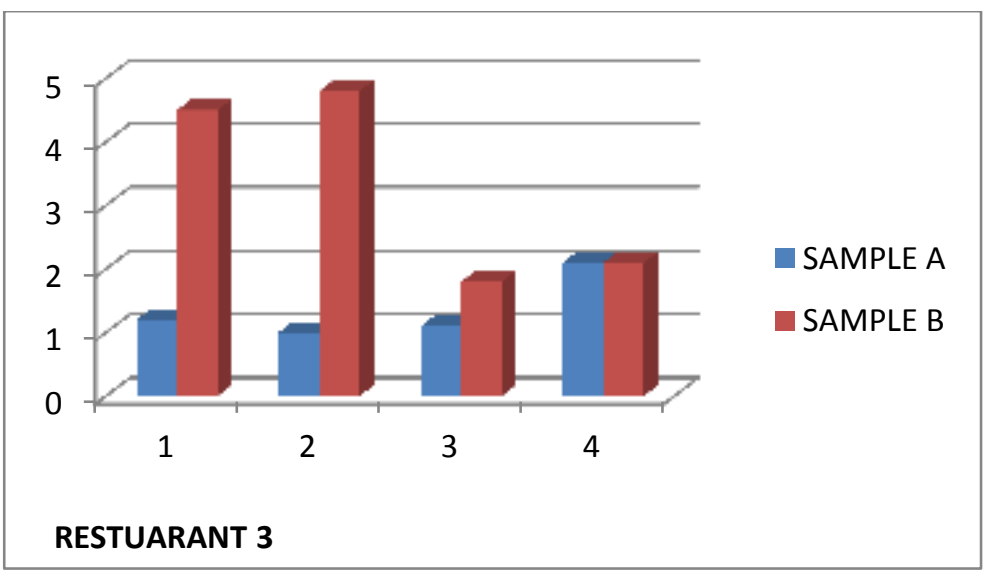

Fig. 3: Bacterial count for Restaurant 3 


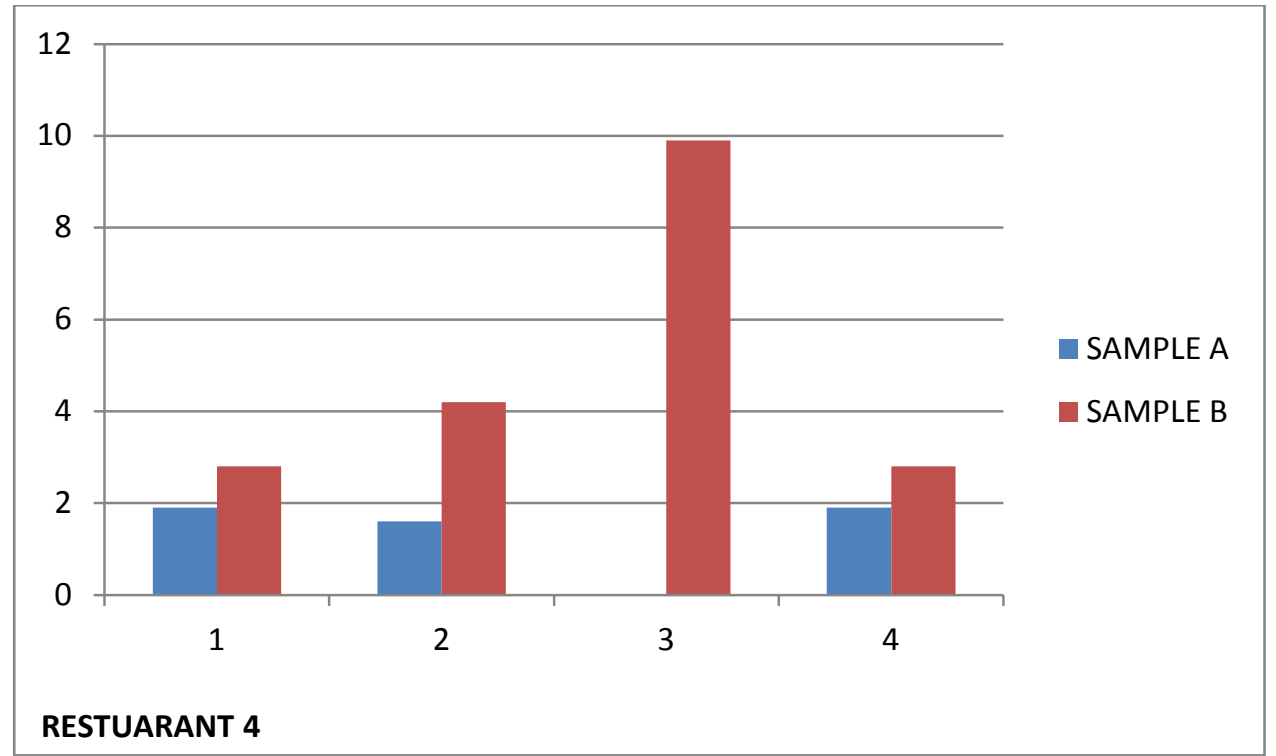

Fig. 4: Bacterial count for Restaurant 4

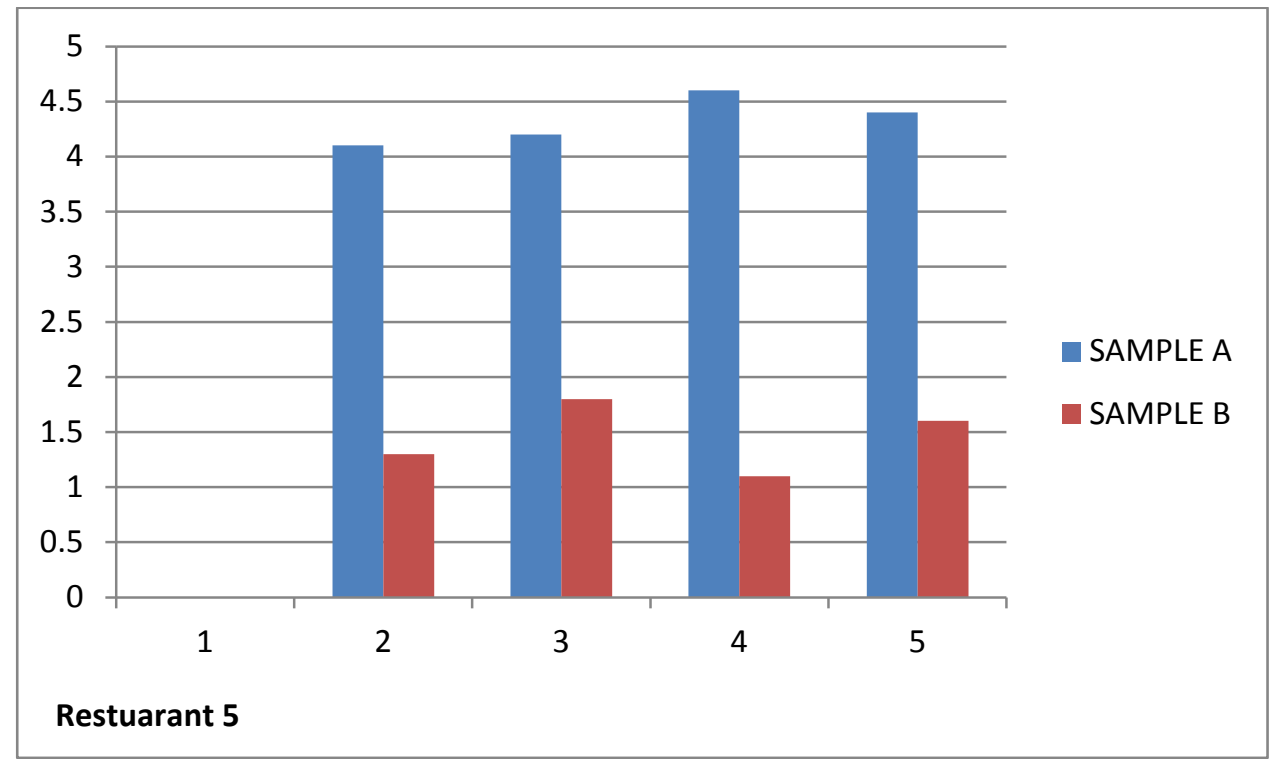

Fig. 5: Bacterial count for Restaurant 3

Quality characteristics of samples obtained

The food quality and characteristics was obtained through questionnaire in which consumers regard the taste and other sensory characteristics of food, health, convenience and the preparation process (e.g. color, taste, appearance, moisture content, texture etc.) are the most important determinants of food quality sold in different restaurants according to the consumers.

The table below illustrates their response:

Table 11: Respondents answer.

\begin{tabular}{|l|l|}
\hline Quality and Characteristics of Food samples & Percentage (\%) \\
\hline Color and appearance & 75 \\
\hline texture & 70 \\
\hline Taste and flavor & 80 \\
\hline Odor & 5 \\
\hline
\end{tabular}




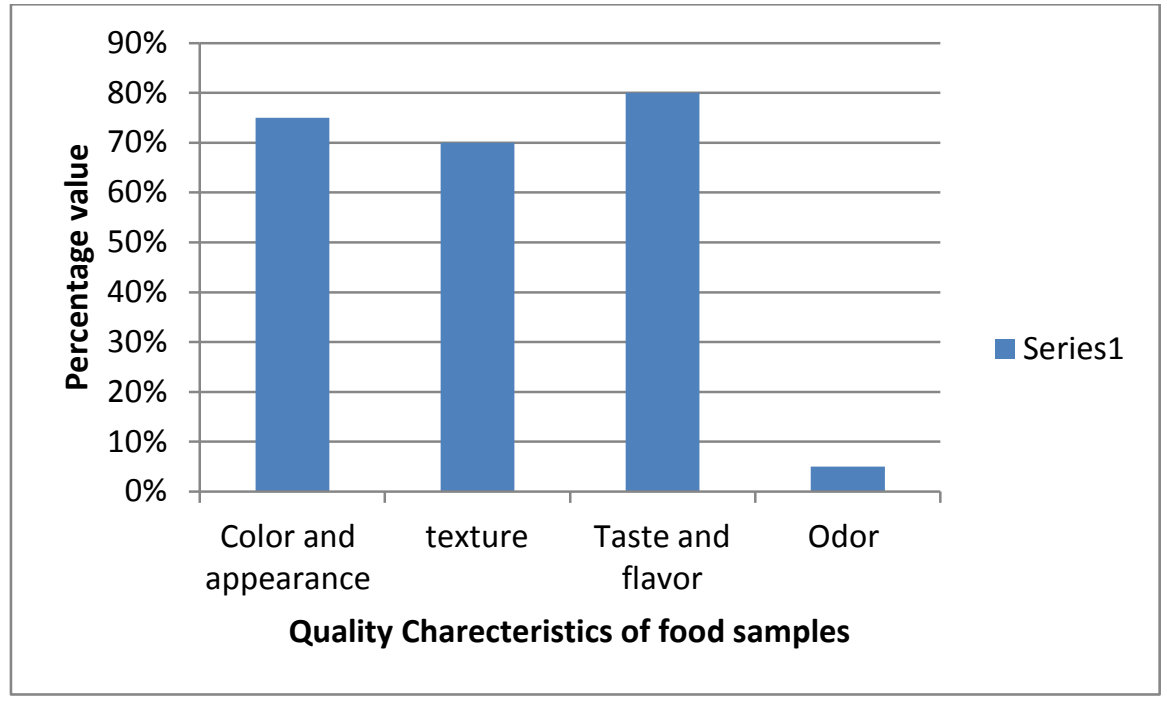

Figure 6. Quality Charecteristics of food samples

\begin{tabular}{|l|c|l|l|}
\hline \multicolumn{2}{|c|}{ Restaurant one } & Restaurant two \\
\hline Sample & Name of food & Sample & Name of Food \\
\hline A & Moi-moi & A & Eguisi Soup \\
\hline B & Beans & B & Jellof Rice \\
\hline
\end{tabular}

\begin{tabular}{|l|c|l|c|}
\hline \multicolumn{2}{|c|}{ Restaurant three } & \multicolumn{2}{l|}{ Restaurant four } \\
\hline Sample & Name of food & Sample & Name of Food \\
\hline A & Starch & A & Stew \\
\hline B & Banga Soup & B & Ogbolor \\
\hline
\end{tabular}

\begin{tabular}{|l|l|}
\hline \multicolumn{1}{|c|}{ Restaurant one } & \\
\hline Sample & Name of food \\
\hline A & Salad \\
\hline B & Fried Rice \\
\hline
\end{tabular}

\section{DISCUSSION}

Pathogenic bacteria are the most common known causes of food contamination and food borne illness. From the analysis, the bacteria isolated; E. spp, staphylococcus aureus, Bacillus Spp, Pseudococcus aureus, pseudomonas auruginosa and Lactobacillus (Ajata et al., 2009).

E.spp, Bacillus causes acute gastroenteritis. These infection causes severe body diahoea and abdominal cramps and watery diarrhea which makes the body loses fluids and electrolyte. (dehydration). This infection can also cause a complication called hemolytic uremic syndrome in which the red blood cells are destroyed and the kidneys fails. Hemolytic uremic syndrome is the principal causes of acute kidney failure in children (Bean et al., 1990).

Naturally, staphylococcus aureus can be described as opportunistic pathogen as it can cause an array of acute infection such as boil, conjunctivitis etc. the presence of staphylococcus aureus is also implicated in the food poisoning which are characterized by vomiting and diarrhea within six hours of consumption of contaminated food due to the presence of entero-toxin produced by staphylococcus aureu (Eric et al., 2010).

The major source of this organism to the sample could be the hands, skin and nose of food handlers. Talking, coughing and sneezing produces a large droplets which could settle in the processing of foods and organism present in this droplet could multiply. Food borne disease can be prevented by adequate hygiene practice during the preparation of food (Scott; 2002). 
In order to ensure that food borne disease are prevented, preparation and storage of foods sold in restaurant must be done in safe and hygiene environment Ajata et al., 2009).

However, the pathogens isolated in this research work are similar to the microorganisms reported by Bankole et al., 2005) and that of (Imonah, 2010).

However, there is the need for educating the vendors and hired helps on safe food handling practice and proper hygienic practices, particularly proper hand washing

\section{CONCLUSION AND RECOMMENDATION}

It was found out from the analysis that samples were contaminated by E. spp, Staphylococcu aureus, Lactobacillus spp, Bacillus spp, Pseudococcus spp, Rhizopus, Aspergillus, Muco spp which indicated possible health hazard such as food intoxication and infection.

Incidence of these micro-organisms in food can be reduced or eradicated by the practice of good personal hygiene by food handlers and prevention of the already prepared food from dust and other sources of contamination such as showcasing in glass enclosure.

It is therefore recommended that personal hygiene should be practice when preparing food, also restaurant foods like salad, beans, moi-moi, plantain etc should be avoided when bad odour or colour changes in them are observed. Utensils used for eating should be clean and free from contaminants.

\section{REFERENCES}

1. Ajata A.G and Atere T.G. (2009), "Bacteriological Assessment and Hygiene Standard" of food canteen in Kwara State Polytechnic, Illorin, Nigeria.

2. Bankole Ola (2004), Bacteriological Assessment and Hygiene Standard for food. Jire Publisher Limited, Benin city, Edo State.

3. Bean N., Griffin P.M, Giolding J.S and Ivey C.B (1990). "Food Borne Diseases Outbreak 5 years summary 1983-1987 J. food prof, 53.711" Bergarys Manual of Determinative bacteriology and Atlases of Microbiology of olds.

4. Cliffs notes (2000), Food spoilage Willey publishing inc. alright reserved.

5. Eric S. Donkon, K. Leff and Hukki, B. (2010). "Bacterial Contamination of tisre- suya, A Nigeria meat product Pakistan Journal of Nutrition 5(5):458-460

6. FDA (2009), "Food Development Agency Ministry of Health Services".

7. Food Safety Information Council (2003).

8. Kumar M.D Agarheal, M. Ghosh and A. Ganglioli (2006). Microbiological Safety of Street Vended food fruit chat in patiala city India J.Med Microbial.

9. Mahala D. P.R.G Khade and V.K Valdy (2008). Microbiological Analysis of Street Vended fruit from Mumbai city India internet food sat 10:31.

10. Odika Solomon Enudi (2011). Microbiological Assessment and Hygienic Standard of food canteen in Delta Polytechnic Ozoro Nigeria.

11. Scott E. (2000), "Food Safety in the Home and Safe Handling of Foods (Farber J.M and Todd E.C.O Eds).

12. Sheth M.R Gurudasan and R. Mudbiduri (2005). Screening for Pathogenic Micro-organisms in Street Vended. Bhelpuri in urban Vendodara. A HCCP approach J. Food Sci Technol 42:395-399.

13. Wikipedia (2018)

14. WHO (2001), Background paper, developing food Safety Strategy. WHO Strategic Planning Meeting, geneua. http://appswhointst/document/bacground620 